\title{
KONFLIK PERAN GANDA PADA DOSEN PEREMPUAN DITINJAU DARI DUKUNGAN SOSIAL KELUARGA
}

\author{
Tyas Martika Anggriana, Tita Maela Margawati, Silvia Yula Wardani
}

\begin{abstract}
Abstrak
Bekerja merupakan salah satu aspek terpenting dalam kehidupan individu dewasa. Fenomena yang terjadi di masyarakat pada era globalisasi adalah semakin banyaknya perempuan yang bekerja di luar rumah. Kecenderungan perempuan untuk bekerja menimbulkan persoalan. Ketika di tempat kerja, perempuan dihadapkan pada tuntutan pekerjaan, sedangkan ketika sudah pulang ke rumah, perempuan akan dihadapkan pada peran domestik. Dalam menghadapi peristiwaperistiwa yang menekan, individu membutuhkan dukungan sosial. Individu yang memiliki dukungan sosial yang tinggi dapat mengatasi stres secara lebih berhasil dibanding dengan individu yang kurang memperoleh dukungan sosial.

Penelitian ini dilakukan di IKIP PGRI MADIUN. Penelitian dilakukan dengan menggunakan pendekatan kuantitatif-non eksperimental expost-facto. Teknik pengumpulan data yang digunakan adalah dengan menggunakan kuesioner. Teknik analisis data yang digunakan adalah analisis regresi.

Hasil analisis data penelitian menunjukkan bahwa terdapat pengaruh signifikan dukungan sosial keluarga terhadap konflik peran ganda. Semakin tinggi dukungan sosial keluarga maka semakin rendah konflik peran ganda, dan sebaliknya semakin rendah dukungan sosial keluarga maka semakin tinggi konflik peran ganda.
\end{abstract}

Kata Kunci : Konflik Peran Ganda, Dukungan Sosial Keluarga

* Tyas Martika Anggriana, Tita Maela Margawati, Silvia Yula Wardani adalah Dosen Program Studi Bimbingan dan Konseling Fakultas Ilmu Pendidikan IKIP PGRI MADIUN. 


\section{PENDAhuluan}

Bekerja merupakan salah satu aspek terpenting dalam kehidupan individu dewasa. Bekerja dapat diartikan sebagai suatu upaya yang dilakukan oleh individu dengan mengerahkan tenaga dan pikirannya untuk mengaktualisasikan dirinya dan diarahkan pada pencapaian tujuan tertentu.

Individu bekerja karena dilandasi oleh dorongan untuk memenuhi kebutuhan, baik kebutuhan fisiologis maupun psikologis. Kebutuhan fisiologis adalah yang terkait dengan pemenuhan kebutuhan sandang, pangan dan papan. Sedangkan kebutuhan psikologis terkait dengan pemenuhan kebutuhan interaksi sosial, pencapaian status sosial ekonomi, kebutuhan mengaktualisasikan diri, dan lain sebagainya.

Fenomena yang terjadi di masyarakat pada era globalisasi adalah semakin banyaknya perempuan yang bekerja di luar rumah. Motivasi yang mendorong perempuan bekerja tidak hanya didorong oleh kebutuhan ekonomi keluarga, melainkan juga ada dorongan untuk mengaplikasikan keterampilan dan pengetahuan yang dimiliki, mengekspresikan diri di tengah-tengah keluarga dan masyarakat, mengembangkan potensi yang dimiliki serta mengaktualisasikan diri.

Kecenderungan perempuan untuk bekerja menimbulkan persoalan. Ketika di tempat kerja, perempuan dihadapkan pada tuntutan pekerjaan, misalnya tekanan kerja yang berasal dari beban kerja yang berlebihan dan pekerjaan yang harus segera diselesaikan sesuai dengan deadline. Setelah melewati jam kerja dan pulang ke rumah, perempuan akan dihadapkan pada tuntutan keluarga, misalnya berhubungan dengan waktu dan tenaga yang dibutuhkan untuk menyelesaikan pekerjaan rumah tangga, mengatur waktu dengan suami dan anak serta menyelesaikan urusan domestik lainnya dengan baik. Hal ini disebut sebagai konflik peran ganda.

Menurut Netemeyer, dkk (Hennesy, 2005) konflik peran ganda adalah konflik yang muncul akibat tanggung jawab yang berhubungan dengan pekerjaan mengganggu permintaan, waktu, dan ketegangan dalam keluarga. Sedangkan Frone, Russell \& Cooper (1992) mendefinisikan konflik pekerjaan keluarga sebagai konflik peran yang terjadi pada karyawan, dimana di satu sisi ia harus melakukan pekerjaan di kantor dan di sisi lain harus memperhatikan keluarga secara utuh, sehingga sulit membedakan antara pekerjaan mengganggu keluarga dan keluarga mengganggu pekerjaan. 
Penelitian Netemeyer (1996) menyatakan bahwa hubungan antara keluarga dan pekerjaan ini bersifat dua arah, oleh karena itu pekerjaan dapat berpengaruh pada keluarga dan sebaliknya, sehingga kedua komponen konflik peran ganda dapat dijelaskan sebagai berikut: (a) FIW (family interference with work). Konflik peran ganda dapat muncul akibat urusan keluarga mengganggu urusan pekerjaan, artinya bentuk konflik antar peran dimana tuntutan yang muncul di dalam keluarga mengganggu pelaksanaan tanggung jawab dalam pekerjaan. (b) WIF (work interference with family). Konflik peran ganda dapat muncul akibat urusan pekerjaan mengganggu urusan keluarga, artinya bentuk konflik antar peran dimana tuntutan yang muncul didalam pekerjaan mengganggu pelaksanaan tanggung jawab dalam keluarga.

Menurut Stonner dkk (1990), faktor - faktor yang mempengaruhi konflik peran ganda adalah: (a) Time Pressure, jika waktu yang digunakan untuk bekerja lebih banyak, maka waktu yang digunakan untuk keluarga akan semakin sedikit. (b) Family size dan support, jika anggota keluarga semakin banyak jumlahnya maka akan semakin banyak konflik yang akan timbul. Apabila dengan banyaknya jumlah anggota keluarga yang memberikan dukungan maka akan sedikit terjadi konflik. (c) Job Satisfaction, konflik akan dirasakan lebih sedikit apabila kepuasan kerja seorang karyawan tersebut tinggi. (d) Marital and life satisfaction, apabila seorang perempuan bekerja, maka semakin banyak konsekuensi negatif dalam pernikahannya. (e) Size of firm, konflik peran ganda mungkin juga dipengaruhi oleh banyak karyawan yang bekerja di perusahaan tersebut.

Dalam menghadapi peristiwa-peristiwa yang menekan, individu membutuhkan dukungan sosial. Individu yang memiliki dukungan sosial yang tinggi dapat mengatasi stres secara lebih berhasil dibanding dengan individu yang kurang memperoleh dukungan sosial (Taylor, 2000). Salah satu sumber dukungan sosial adalah keluarga. Keluarga rnerupakan tempat bercerita dan mengeluarkan keluhan-keluhan bila individu mengalami persoalan (Irwanto, 2002). Keluarga adalah lingkungan yang selalu memberikan dukungan emosional untuk menguatkan individu dalam menghadapi segala tekanan yang terjadi dalam kehidupan sehari-hari. Ketika individu mendapatkan prestasi dalam pekerjaannya, keluarga akan memberikan dukungan dan penghargaan guna peningkatan pencapaian prestasi yang lebih baik. Sebaliknya, ketika sedang menghadapi kondisi yang menekan, individu akan mendapatkan kepedulian, empati dan perhatian dari anggota keluarga.

Saroson (Smet, 1994) menyatakan bahwa dukungan sosial adalah adanya transaksi interpersonal yang ditunjukkan dengan memberikan bantuan pada individu lain, dimana bantuan itu umumnya diperoleh dari orang yang berarti bagi individu yang bersangkutan. Dukungan sosial dapat berupa pemberian infomasi, bantuan tingkah laku, ataupun materi yang didapat dari hubungan sosial akrab yang dapat membuat individu merasa 
diperhatikan, bernilai, dan dicintai. Gottlieb (Smet, 1994) menyatakan dukungan sosial terdiri dari informasi atau nasehat verbal maupun non verbal, bantuan nyata, atau tindakan yang didapatkan karena kehadiran orang lain dan mempunyai manfaat emosional atau efek perilaku bagi pihah penerima.

House (Smet, 1994) menyebutkan jenis-jenis dukungan sosial keluarga meliputi: (a) Dukungan emosional, (b) Dukungan penghargaan, (c) Dukungan instrumental, (d) Dukungan informatif. Dukungan sosial dapat bersumber dari: (a) orang-orang yang selalu ada sepanjang hidupnya, yang selalu bersama dengannya dan mendukungnya, (b) individu lain yang sedikit berperan dalam hidupnya dan cenderung mengalami perubahan sesuai dengan waktu, (c) individu lain yang sangat jarang memberi dukungan dan memiliki peran yang sangat cepat berubah (Kahn \& Antonoucci dalam Orford, 1992).

Menurut Undang-Undang Nomor 14 Tahun 2005 tentang Guru dan Dosen mendefinisikan Dosen adalah pendidik profesional dan ilmuwan dengan tugas utama mentransformasikan, mengembangkan, dan menyebarluaskan ilmu pengetahuan, teknologi, dan seni melalui pendidikan, penelitian, dan pengabdian kepada masyarakat. Dalam melaksanakan tugas keprofesionalan, dosen berkewajiban melaksanakan pendidikan, penelitian dan pengabdian kepada masyarakat; merencanakan, melaksanakan proses pembelajaran, serta menilai dan mengevaluasi hasil pembelajaran; meningkatkan dan mengembangkan kualifikasi akademik dan kompetensi secara berkelanjutan sejalan dengan perkembangan ilmu pengetahuan, teknologi, dan seni. Hal tersebut menunjukkan bahwa kewajiban yang harus dilakukan oleh seorang dosen tidak hanya terbatas pada kegiatan mengajar di dalam ruang kuliah, namun masih banyak kewajiban lain yang harus dilakukan oleh seorang dosen di luar jam mengajar. Berbagai kewajiban dosen tersebut menuntut curahan tenaga, waktu dan pikiran yang harus bisa diatur dengan baik.

Berdasarkan uraian latar belakang masalah, peneliti tertarik untuk mengetahui konflik peran ganda ditinjau dari dukungan sosial keluarga pada dosen perempuan IKIP PGRI Madiun.

\section{METODE PENELITIAN}

Berdasarkan pada kerangka berpikir yang ada, penelitian dilakukan dengan menggunakan pendekatan kuantitatif-non eksperimental. Penelitian ini ditujukan untuk mengetahui hubungan suatu variabel dengan variabel lain. Hubungan antara satu variabel dengan beberapa variabel lain dinyatakan dengan besarnya koefisien korelasi dan keberartian (signifikansi) secara statistik (Sukmadinata, 2009). Penelitian ini akan membuktikan pengaruh dukungan sosial keluarga terhadap konflik peran ganda.

Konflik peran ganda adalah konflik yang muncul akibat terjadinya pertentangan antara peran individu di dalam keluarga dan di tempat kerja. Dukungan sosial keluarga adalah kenyamanan fisik dan psikologis yang diberikan oleh keluarga kepada anggota keluarga lainnya. 
Penelitian ini dilakukan di IKIP PGRI MADIUN. IKIP PGRI MADIUN adalah sebuah LPTK (Lembaga Pendidikan Tenaga Kependidikan) yang beralamat di Jl. Setia Budi No. 85 Madiun. IKIP PGRI MADIUN memiliki 13 program studi yang sudah terakreditasi oleh BAN-PT Kemendikbud.

IKIP PGRI MADIUN memiliki 196 tenaga pengajar yang memiliki kualifikasi akademik sesuai dengan program studinya masing-masing. Dari 196 tenaga pengajar tersebut, 87 orang diantaranya adalah perempuan.

Populasi dalam penelitian ini dibatasi pada dosen perempuan yang telah menikah, berjumlah 69 orang. Hal ini didasarkan pada kesesuaian dengan karakteristik penelitian. Berdasarkan jumlah populasi tersebut, dilakukan pengambilan sampel dengan menggunakan rumus Taro Yamane, sehingga diperoleh sampel sejumlah 59 orang. Teknik pengambilan sampel dilakukan dengan menggunakan random sampling.

Teknik pengumpulan data pada penelitian ini dengan menggunakan metode angket. Angket (kuesioner) merupakan suatu teknik pengumpulan data yang dilakukan dengan cara memberi seperangkat pertanyaan atau pernyataan tertulis kepada responden untuk dijawabnya (Sugiyono, 2012).

Data yang terkumpul dari lapangan, akan di analisis menggunakan analisis regresi untuk mengetahui ada tidaknya pengaruh antar variabel. Analisis regresi adalah analisis statistika yang memanfaatkan hubungan antara dua atau lebih peubah kuantitatif sehingga salah satu peubah dapat diramalkan dari peubah lainnya (http://web.ipb.ac.id). Kerlinger (2004: 929) mendefinisikan analisis regresi adalah suatu metode untuk mengkaji akibat-akibat dan besarnya akibat dari lebih dari satu variabel bebas terhadap satu variabel terikat, dengan menggunakan prinsip-prinsip korelasi dan regresi.

\section{HASIL DAN PEMBAHASAN}

Analisis deskriptif yang dilakukan terhadap angket dukungan sosial keluarga diketahui bahwa frekuensi tertinggi dukungan sosial keluarga berada pada kategori tinggi. Adapun distribusi frekuensi data angket dukungan sosial keluarga adalah sebagai berikut:

Tabel 1. Distribusi Frekuensi Angket

Dukungan Sosial Keluarga

\begin{tabular}{|l|c|c|c|}
\hline \multicolumn{1}{|c|}{ Kategori } & Interval & Frekuensi & Persentase \\
\hline Sangat Tinggi & $41-45$ & 14 & $23,73 \%$ \\
\hline Tinggi & $36-40$ & 36 & $61,02 \%$ \\
\hline Rendah & $31-35$ & 8 & $13,56 \%$ \\
\hline Sangat Rendah & $25-30$ & 1 & $1,69 \%$ \\
\hline
\end{tabular}


Analisis deskriptif yang dilakukan terhadap angket konflik peran ganda diketahui bahwa frekuensi tertinggi subjek penelitian yang mengalami konflik peran ganda berada pada kategori sedang. Distribusi frekuensi data angket konflik peran ganda adalah sebagai berikut:

Tabel 2. Distribusi Frekuensi Angket Konflik Peran Ganda

\begin{tabular}{|l|c|c|c|}
\hline \multicolumn{1}{|c|}{ Kategori } & Interval & Frekuensi & Persentase \\
\hline Sangat Tinggi & $31-35$ & 3 & $5,08 \%$ \\
\hline Tinggi & $26-30$ & 23 & $38,98 \%$ \\
\hline Sedang & $21-25$ & 26 & $44,07 \%$ \\
\hline Rendah & $15-20$ & 7 & $11,87 \%$ \\
\hline
\end{tabular}

Berdasarkan uji analisis regresi untuk mengetahui pengaruh dukungan sosial keluarga terhadap konflik peran ganda diperoleh nilai Standarized Beta sebesar -0,317 dengan taraf signifikansi 0,014 ( $\mathrm{p}<0,05$; signifikan), berarti ada pengaruh signifikan dukungan sosial keluarga terhadap konflik peran ganda. Arah pengaruh dukungan sosial keluarga terhadap konflik peran ganda bersifat negatif, artinya semakin tinggi dukungan sosial keluarga maka semakin rendah konflik peran ganda, sebaliknya semakin rendah dukungan sosial keluarga maka semakin tinggi konflik peran ganda.

Konflik peran ganda perempuan yang bekerja tidak terlepas dari pengaruh dan dukungan dari keluarga terutama dukungan dari suami. Suami perlu memberikan dukungan emosional, misalnya memberikan kenyamanan sehingga istri terbebas dalam kondisi keluarga yang penuh dengan tekanan. Dukungan instrumental dapat diberikan oleh suami dalam bentuk keikutsertaannya dalam mengurus rumah tangga dan berbagi peran dalam mengasuh anak. Selain itu, motivasi dan penghargaan terhadap prestasi kerja yang diraih oleh istri juga dapat mengurangi konflik peran ganda yang dialami oleh istri.

Hasil penelitian ini sejalan dengan penelitian yang dilakukan oleh Apollo \& Cahyadi (2012) yang menunjukkan hasil dukungan sosial keluarga mempunyai hubungan negatif yang sangat signifikan dengan konflik peran ganda perempuan menikah yang bekerja. Besarnya dukungan keluarga dapat menekan munculnya konflik peran ganda pada perempuan menikah yang bekerja. Dukungan sosial keluarga, terutama dari suami dapat mengurangi tingkat konflik peran ganda perempuan menikah yang bekerja, karena dukungan sosial keluarga memainkan peranan penting pada proses stres dalam pekerjaan baik di luar rumah sebagai perempuan karir maupun di dalam rumah sebagai isteri. Dukungan terhadap karir isteri adalah suatu sikap positif yang ditunjukkan oleh suami berupa dorongan atau pemberian reward positif terhadap kemajuan karir isteri. 
Tabel 5. Hasil Analisis Regresi Pengaruh Dukungan Sosial Keluarga terhadap Konflik Peran Ganda

\begin{tabular}{|l|c|c|c|c|}
\hline \multicolumn{1}{|c|}{ Variabel } & $\boldsymbol{R}$ & sig & $\mathbf{R}^{2}$ & \multicolumn{1}{c|}{ Ket. } \\
\hline $\begin{array}{l}\text { Konflik peran ganda dan Job } \\
\text { Performance }\end{array}$ & $-0,317$ & 0,014 & 0,101 & Ada pengaruh signi fikan \\
\hline
\end{tabular}

\section{KESIMPULAN}

Berdasarkan hasil analisis data dan pembahasan dapat disimpulkan bahwa ada pengaruh dukungan sosial keluarga terhadap konflik peran ganda Dosen Perempuan IKIP PGRI MADIUN.

\section{REFERENSI}

Analisis Regresi. http://web.ipb.ac.id

Apollo \& Cahyadi, A. 2012. Konflik Peran Ganda Perempuan Menikah Yang Bekerja Ditinjau Dari Dukungan Sosial Keluarga dan Penyesuaian Diri. Widya Warta No. O2 Tahun XXXV I/ Juli 2012

Astrani Maherani. 2008. Pengaruh Konflik Peran Ganda dan Fear Of Success terhadap Kinerja Wanita Berperan Ganda. Jakarta: Universitas Gunadarma

Dessler, G. 2009. Manajemen Sumber Daya Manusia. Jakarta: Indeks

Gibson. 2003. Organisasi: Perilaku, Struktur, dan Proses. Jakarta: Erlangga.

Greenhaus, J.H. \& Beutell, N.J. 1985. Sources of conflict between work and family roles. Academy of Management Review, 10 (1), 76-88.

Hennessy, K. D. 2005. Work-family conflict self-efficacy: Ascale validationstudy. http://drum.umd.edu/dspace/bitstream/1903/2526/1/umi-umd-2410.pdf

Irwanto. 2002. Psikologi Umum. Jakarta: PT Prenhallindo

Johana Purba, Aries Yulianto, dan Ervy Widyanti. 2007. Pengaruh Dukungan Sosial Terhadap Burnout Pada Guru. Jurnal Psikologi Vol. 5 No. 1, 77-87

Kerlinger, F. N. 2004. Asas-Asas Penelitian Behavioral. Yogyakarta: Gadjah Mada University Press

M. As'ad. 2003. Psikologi Industri: Seri Sumber Daya Manusia. Yogyakarta: Liberty

Netemeyer, R.G., J.S.Boles , R.Mc. Murrian. 1996. Development and Validation of Work-Family Conflict Scales. Journal of Applied Psychology, Vol. 81 No. 4, pp. 400-410

Santrock, J. W. 2002. Life Span Development. Jilid II. Jakarta: Erlangga.

Simon, T. L. .2002. The exploration of the working mother's plight through psychoanalytic, feminist and intersubjective approach. San Francisco Bay Campus Alliant International University. http://www.proquest.com.

Smet, B. 1994. Psikologi Kesehatan. Jakarta: PT. Gramedia Widiasarana Indonesia

Sugiyono. 2012. Metode Penelitian Pendidikan: Pendekatan Kuantitatif, Kualitatif dan R\&D. Bandung: Alfabeta

Sukmadinata, N.S. 2009. Metode Penelitian Pendidikan. Bandung: PT. Remaja Rosdakarya

Taylor, S.E., Peplau, L.A., Sears, D.O. 2000. Social Psychology. New Jersey: Prentice-Hall 